конференций, совещаний и ЦК ВКП(б). - М.; Л. : НКПрос РСФСР : Государственное издательство, 1929. - 111 с. З. Козлова Л. А. Институт красной профессуры (1921-1938) / Л. А. Козлова // Социологический журнал. - 1997. - № 4. - С. 209-220. 4. Кузнецова Т. Ф. Картина мира / Т. Ф. Кузнецова. - [Электронный ресурс]: Информационный гуманитарный портал «Знание. Понимание. Умение». - 2008. - №4 - (Серия : «Культурология»). - Режим доступа: http://www.zpu-journal.ru/e-zpu/2008/4/Kuznetsova/. 5. Лагно А. Р. Институт ректорства в Московском университете 1920-х - 1930-х гг. / А. Р. Лагно - [Электронный ресурс]: Государственное управление. Электронный вестник. - 2011. - № 29. - Режим доступа: http://ejournal.spa.msu.ru/images/File/2011/29/Lagno.pdf. 6. Первушина О. В. Картина мира: возможность феноменологического похода / О. В. Первушина // Мир науки, культуры, образования. - 2009. - № 5 (17). - С. 123-126. 7. Проценко В. О. До проблеми викладання гуманітарних дисциплін у технічному ВНЗ / В. О. Проценко // Вісник ЛНУ імені Тараса Шевченка. - 2012. - № 10 (245). С. 88-95. 8. Синхронистическая таблица IX-XX вв. Россия-Запад-Восток / А. Т. Степанищев, Д. Н. Филиповых. - М. : Гуманитар. изд. центр ВЛАДОС, 2007. - 512 с. 9. Философский энциклопедический словарь [состав. Л.Ф. Ильичев и др.]. - М. : Советская энциклопедия, 1983. 840 с. 10. Фрумкин К. Клиповое мышление и судьба линейного текста // [Электронный ресурс] / К. Фрумкин. - Ineternum. - 2010. - № 1. - Режим доступа: http://nounivers.narod.ru/pub/kf_clip.htm.

УДК 378.14

I. П. Дроздова,

доктор педагогічних наук, доиент, Харківський національний автомобільно-дорожній університет

\title{
СЕМІНАРСЬКІ ТА ПРАКТИЧНІ ЗАНЯТТЯ ДЛЯ РОЗВИТКУ КРЕАТИВНИХ УМІНЬ СТУДЕНТІВ ІЗ ПРОФЕСІЙНОГО МОВЛЕННЯ ЗА ФАХОМ
}

Дроздова І. П. Семінарські та практичні заняття для розвитку креативних умінь студентів із професійного мовлення за фахом.

У статті проаналізовано специфіку семінарських і практичних занять із метою розвитку креативних умінь студентів із професійного мовлення за фахом, визначено і запропоновано приклади моделей семінарського і практичного занять як ефективних організаційних форм роботи у вищій школі.

Ключові слова: семінарські та практичні заняття, професійне мовлення, види створюваних комунікативних ситуацій, засоби контролю, матеріальне забезпечення.

Дроздова И. П. Семинарские и практические занятия для развития креативных умений студентов в профессиональной речи по специальности.

В статье проанализировано специфику семинарских и практических занятий с целью развития креативных умений студентов в профессиональной речи по специальности, определено и предложено примеры моделей семинарского и практического занятий как эффективных организационных форм работы в высшей школе.

Ключевые слова: семинарские и практические занятия, профессиональная речь, виды создаваемых коммуникативных ситуаций, способы контроля, материальное обеспечения.

Drozdova I. P. Seminars and workshops for development of creative abilities of Students of nonphilological profile concerning professional communication on specialty.

The paper analyzes the specifics of seminars and workshops with the aim of developing creative skills of students concerning professional communication on specialty is determined, and examples of models of seminars and workshops as effective organizational forms of work in high school are offered.

Key words: seminars and workshops, professional communication of students, types of created communicative situations, control methods, material supply.

Важливими формами організації навчальної діяльності студентів-нефілологів у ВНЗ з метою розвитку їхнього професійного мовлення є семінарські та практичні заняття. Як і лекції, вони мають свій план проведення залежно від мети заняття та дидактичних комунікативних цілей. У системі ВНЗ на нефілологічних факультетах такі заняття повинні формувати креативні вміння студентів із професійного мовлення за фахом. 
Семінар є організаційною формою, у процесі якої викладач організовує дискусію навколо попередньо визначених тем, до яких студенти готують тези виступів на основі індивідуально виконаних завдань або рефератів (це може бути обговорення фахової термінології, питання культури мовлення тощо).

У практиці роботи ВНЗ переважно культивуються три типи семінарів: які сприяють поглибленому вивченню певного систематичного курсу; вивченню окремих основних або найбільш важливих тем (проблем) курсу; дослідницького характеру 3 незалежною від лекцій тематикою (спецсемінари) [2]. Залежно від часу проведення указані семінари поділяються на проміжні, рубіжні та підсумкові тощо [ $3 ; 5 ; 6]$.

Успіх семінарів, активність студентів на них закладається на лекції, яка, як правило, передує семінару. Лекційний курс, його змістовність, глибина, емоційність значною мірою визначає рівень семінару. Головне, що забезпечує успіх семінару - інтерес аудиторії до обговорюваних проблем. Семінарські заняття забезпечують розвиток творчого професійного мислення, пізнавальної мотивації і професійного використання знань у навчальних умовах [2, с.179]. Професійне використання знань, на нашу думку, становить вільне володіння мовою професії, тобто точне оперування термінами, поняттями та визначеннями.

Виходячи 3 того, що семінар у ВНЗ є груповим заняттям під керівництвом викладача, ми вважаємо що основні завдання полягають у реалізації таких цілей: поглибити і закріпити у студентів знання, отримані на лекціях і у процесі самостійної роботи; перевірити ефективність і результативність самостійної роботи студентів над навчальним матеріалом 3 української мови професійного спрямування; прищепити студентам навички пошуку, риторичних умінь узагальнення і викладення навчального матеріалу в студентській аудиторії; виробити уміння формулювати, обгрунтувати i викладати власне судження з обговорюваних питань, уміння відстоювати свої погляди.

Семінар - активний метод навчання, у застосуванні якого має переважати продуктивно-перетворювальна діяльність студентів. Він має розвивати і закріплювати у студентів навички самостійної роботи, уміння складати плани теоретичних доповідей, їх тези, готувати розгорнуті повідомлення і виступати з ними перед аудиторією, брати участь у дискусії й обговоренні, формувати риторичні навички й уміння 3 професійних питань. Отже, семінар не зводиться до закріплення або копіювання знань, отриманих на лекції, його завдання значно ширше, складніше і цікавіше.

Mema cmammi - проаналізувати специфіку семінарських і практичних занять із метою розвитку креативних умінь студентів із професійного мовлення за фахом, визначити і запропонувати приклади моделей семінарського і практичного занять як ефективних організаційних форм роботи у вищій школі.

Студентам до проведення семінару видається план, що слугує основним методичним документом для організації їхньої самостійної роботи. Обов'язковими його компонентами $€$ : тема, дидактичні і виховні цілі заняття, організаційно-методичні вказівки, навчальні питання, що підлягають розгляду, теми доповідей, повідомлень, рефератів, рекомендована література. Зрозуміло, при цьому важливо ураховувати, що до одного двохгодинного семінару студент може готуватися не більш, ніж 4-5 годин і за цей час прочитати, обдумати, якщо треба, законспектувати не більш 60 сторінок тексту, тобто обсяг літератури, що відпрацьовується студентами для підготовки до семінару, має бути мінімальним. Наразі викладач наштовхує студентів на шлях неглибокої і формальної підготовки.

Реалізація пізнавальної мети в ході семінару потребує від викладача умілого методичного керування. На всіх етапах студенти працюють або під безпосереднім керівництвом викладача (особливо характерно для першого курсу ВНЗ), або в режимі консультування. Порядок обговорення питань плану може бути найрізноманітнішим, він залежить від форми семінару і тих цілей, що ставляться перед цим заняттям для групи студентів. В умовах ВНЗ найчастіше використовуються три схеми: реферативно- 
доповідна, питально-відповідна і змішана. 3 метою активізації семінарських занять 3 української мови професійного спілкування використовуються методи рецензування, аналізу професійного досвіду та поточних подій, завдань, вправ і практичних завдань.

Успіх семінару завжди залежить від активності студентів, тому другий обов'язок викладача - розвивати й заохочувати це. Важливо, на нашу думку, настійливо навіювати студентам думку, що активність - це не тільки виступи і дискусії, але й уміння слухати. Студентів, зокрема першокурсників, необхідно переконувати, що уміння слухати не менше важлива якість, ніж уміння говорити. Семінар, як і будь-який інший вид навчальних занять, передбачає широке використання засобів наочності й ілюстративного матеріалу. Досвід багатьох викладачів-методистів ВНЗ свідчить про те, що тільки за допомогою засобів наочності вдається досягати високого ступеня емоційного впливу на студентів під час вивчення навчального матеріалу. Пропонуємо приклад моделі семінарського заняття з теми: «Функціональні стилі української мови».

Модель семінарського заняття з теми: «Функціональні стилі української мови».

Метод навчання: семінар. Формулювання педагогічних завдань, що вирішуються в рамках семінару: виявити ступінь засвоєння студентами ключових категорій і понять теми, поглибити їх знання з питань, що виносяться на обговорення, забезпечити формування у студентів власного особистісно-змістовного ставлення до розглянутих навчальних питань, сприяти розвитку у студентів мотиваційної готовності застосовувати отримані знання в майбутній професійній діяльності. Види створюваних комунікативних ситуацій: колективна, групова i, в окремих випадках, діадична. Засоби контролю: контрольні тестові завдання на редагування (три варіанти). Матеріальне забезпечення: виставка літератури (словники, галузеві термінологічні довідники), набір тестових завдань.

Питання семінару: «Функціональні стилі української мови»:

1. Сфери вживання й основні функції у суспільстві стилів сучасної української літературної мови. 2. Загальна характеристика функцій і основних різновидів наукового, офіційно-ділового стилів. 3. Багатство лексичних засобів української мови (доречність $\mathrm{i}$ доцільність уживання синонімів, антонімів, омонімів, паронімів і т.д. у різних стилях мови). 4. Лексико-стилістичний аналіз текстів різних стилів і жанрів із визначенням характерних стильових засобів (лексико-стилістичне редагування речень, виправлення стильових помилок). Наводимо план проведення семінарського заняття в таблиці 1.

План проведення семінарського заняття

Таблиця 1.

\begin{tabular}{|c|c|}
\hline \multicolumn{2}{|c|}{ 1. Вступна частина } \\
\hline Дії викладача & Дії студентів \\
\hline $\begin{array}{l}\text { Перевіряє наявність студентів } \\
\text { семінарському занятті і підготовленість ї до } \\
\text { проведення занять. } \\
\text { Доводить до студентів тему заняття, його } \\
\text { мету, питання, що виносяться на обговорення, } \\
\text { логіку і порядок їх розгляду. } \\
\text { Призначає групу експертів, які за } \\
\text { підсумками заняття мають зробити свій } \\
\text { висновок про ступінь індивідуальної } \\
\text { підготовленості студентів до семінарського } \\
\text { заняття, інструктуєіх. }\end{array}$ & 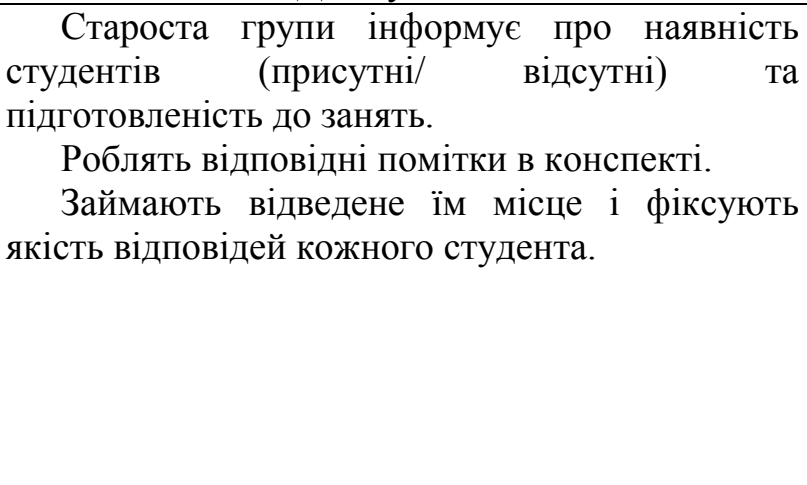 \\
\hline \multicolumn{2}{|c|}{ 2. Основна частина } \\
\hline $\begin{array}{l}\text { Здійснюється фронтальне опитування студентів } \\
3 \text { метою з'ясувати, наскільки глибоко засвоєні } \\
\text { ними ключові категорії і поняття теми. } \\
\text { Питання для дискусії: } \\
\text { - Що таке стиль? } \\
\text { - Які ви знаєте стилі сучасної української мови? }\end{array}$ & $\begin{array}{l}\text { Студенти письмово й усно відповідають на } \\
\text { питання завдань, вибираючи } 3 \text { пропонованих } \\
\text { відповідей правильні. } \\
\text { Слухають повідомлення, роблять помітки в }\end{array}$ \\
\hline
\end{tabular}


- Дайте загальну характеристику функцій i основних різновидів наукового стилю.

- Дайте загальну характеристику функцій i основних різновидів офіційно-ділового стилю.

- Як застосовуються лексичні засоби української мови у різних стилях?

- Які є функціонально-стилістичні типи лексики?

- Що таке запозичена лексика?

- Наведіть приклади лексико-семантичної сполучуваності слів.

- Наведіть приклади різноманітного стилістичного використання фразеологічних засобів.

- Зробіть лексико-стилістичний аналіз тексту наукового стилю

- Зробіть лексико-стилістичне редагування речень офіційно-ділового стилю. конспекті, ставлять питання доповідачу.

Відповідають на питання викладача, доповнюють один одного, ставлять додаткові питання, беруть участь у дискусії

Студенти наводять приклади, записують їх і визначають головні ознаки стилів

Студенти аналізують тексти різних стилів (подані на картках) i записують правильні варіанти.

\begin{tabular}{|c|c|cc|}
\hline \multicolumn{5}{|c|}{ 3. Заключна частина } \\
\hline Надає можливість експертам оцінити & Слухають викладача, роблять помітки в \\
результати індивідуальної участі студентів в & конспекті. & \\
обговоренні питань, що виносяться на семінар. \\
Оцінює результати роботи експертів.
\end{tabular}

У ВНЗ використовуваними $є$ різні види семінарів: семінар 3 елементами проблемності; семінар із використанням «сократівського» методу навчання; семінарбрейнстормінг («мозковий штурм» - максимально напружена креативна мислетворча робота групи студентів з розв'язання інтелектуального завдання у максимально стислий термін); семінар із використанням методу «круглого столу» або аналізу конкретних ситуацій; семінар-бесіда; семінар-диспут; спеціальний семінар; навчальна тематична дискусія, семінар-екскурсія, семінар-дослідження тощо [4, с.15-18].

Практичні та лабораторні заняття [3; 4] спрямовані на поглиблення теоретичного матеріалу й формування практичних умінь та навичок, а також уміння аналізувати й застосовувати здобуті знання для вирішення практичних завдань. Метою практичного заняття є поглиблення наукових знань, здобутих студентами на лекціях та в процесі самостійної роботи і спрямованих на підвищення рівня засвоєння навчального матеріалу, прищеплення вмінь і навичок, розвиток наукового мислення і мовлення студентів [4, c. 24].

Комунікативний зміст практичного заняття 3 курсу «Українська мова (за професійним спрямуванням)» полягає у розширенні, поглибленні, систематизації й деталізації наукових знань із мови, що одержують студенти на лекціях й у процесі самостійної роботи і спрямовані на підвищення рівня засвоєння навчального матеріалу, формування умінь і навичок, розвиток наукового мислення і професійного мовлення студентів, прийняття самостійних рішень у складних виробничих ситуаціях. В організації практичного заняття слід чітко продумати систему контролю рівнів знань, що формуються, систему оцінок, виробити єдині критерії для всіх студентів для визначення ступеня оволодіння професійним мовленням.

Наприклад, основною дидактичною метою практичного заняття «Науковий текст. Структура мовного оформлення» 3 курсу «Українська мова (за професійним спрямуванням)» $€$ засвоєння та узагальнення відомостей про композиційно-структурну організацію наукового тексту: за характером змісту, за способом викладення інформації, лексико-граматичними засобами організації тощо. Разом із дидактичною метою сформульовано професійно-комунікативну мету: сприяти активному опрацюванню композиційно-структурної організації наукового тексту з метою побудови таких текстів за 
основними фаховими дисциплінами, уміти відтворювати жанри наукової літератури у власному усному та писемному мовленні під час професійного спілкування та публічних виступів.

Між дидактичною та комунікативною цілями $є$ глибокий внутрішній зв'язок: дидактичною метою заняття «Науковий текст. Структура мовного оформлення» 3 курсу «Українська мова (за професійним спілкуванням)»є засвоєння і поглиблення знань про лексико-граматичні засоби організації наукового тексту та розпізнавання порушення морфологічних і синтаксичних норм у текстах наукового стилю залежно від способу викладення наукової інформації.

Комунікативною метою заняття $\epsilon$ формування i розвиток навичок роботи 3 науковими текстами за фахом студентів-нефілологів, і дидактична і комунікативна цілі практичного заняття спрямовані на виховання особистості студентів, формування, розвиток і вдосконалення професійного мислення і мовлення майбутніх фахівців під час навчання української мови.

Незалежно від дидактичної мети практичного заняття здійснюється професійно орієнтована комунікативна діяльність студентів на практичному занятті, причому його комунікативна мета сприяє усвідомленню студентом потреби у зростанні мовленнєвої вправності та вдосконаленні практичних навичок професійно-орієнтованого спілкування.

У системі навчання професійного мовлення студентів засобами української мови істотну роль відіграє черговість лекцій і практичних занять. Лекції $є$ першим кроком підготовки студентів до практичних занять, що формують професійне мовлення. Питання, поставлені в ній, на практичному занятті набувають конкретне вираження і рішення. Подібного аналога лекція серед інших видів занять не має. Лекція і практичні заняття не тільки мають суворо чергуватися в часі, але й бути методично зв'язані проблемним професійно орієнтованим навчальним матеріалом або ситуацією, як, наприклад, лекція i практичне заняття за темами «Мовленнєва поведінка у професійно-службових стосунках».

Наш досвід переконує, що чим меншою мірою лекційний матеріал корелює із матеріалом, що розглядається на практичному занятті, тим важче лектору залучити студентів до творчої діяльності. Зміст практичного заняття реалізується в програмі курсу української мови за професійним спрямуванням як план практичного заняття, що, наприклад, за темою «Система жанрів наукової літератури» віддзеркалює інформаційну насиченість заняття, сприяє тому, що студенти орієнтуються на відповідні типи завдань, спрямовані на написання різноманітних жанрів наукової літератури, а саме: анотації, рецензії, реферату, тез, наукової статті, резюме тощо, які допомагають опанувати дисципліни за фахом.

Педагогічний досвід також свідчить, що на практичних заняттях не можна обмежуватися виробленням лише практичних навичок і вмінь розв'язання завдань, виконання вправ, складання, опрацювання наукових текстів за зразками тощо. Студенти мають завжди бачити провідну ідею курсу i iï зв'язок із майбутньою практичною професійною діяльністю. Мета занять повинна бути зрозумілою не тільки викладачу, але й студентам, що додає навчальній роботі життєвий характер, стверджує необхідність оволодіння досвідом виробничої діяльності, пов’язує їх із практикою майбутньої професії.

За таких умов обов'язок викладача полягає в тому, щоб більше показувати студентам практичну значущість знання української мови. Під час проведення семінарських і практичних занять ми дотримувалися таких основних принципів навчання: єдність розвитку мовлення і мислення; зв'язок усного і писемного мислення й роботи 3 розвитку культури мовлення, опрацювання теоретичних розділів курсів за фахом студентів; зв'язок роботи з розвитку культури мовлення з вивченням дисциплін фахового спрямування.

Перспективи подальших пошуків у напрямку дослідження полягають у використанні засобів активізації творчого мислення в процесі проведення семінарських і практичних занять, що зумовить досягнення високого рівня розвитку професійного 
мислення, удосконалення фахових умінь та навичок у майбутній діяльності, підвищення навчальної та ділової компетенції.

\title{
Література
}

1. Бандурка О. М. Основи педагогічної техніки / О.М.Бандурка, В. О. Тюрина, О. І. Федоренко. - Х. : ТИТУЛ, 2006. - 176 с. 2. Вітвицька С. Основи педагогіки вищої школи: підруч. за модульно-рейтинговою системою навчання для студентів магістратури / С. Вітвицька. К. : Центр навч. літ., 2006. - 384 с. 3. Кайдалова Л. Г. Модульна технологія навчання: [навч.метод. посіб. для викладачів і студентів вищ. навч. закладів] / Л. Г. Кайдалова, 3. М. Мнушко. Х. : Вид-во НФАУ: Золоті сторінки. - 2002. - 86 с. 4. Методика проведення занять у вищому навчальному закладі: метод. реком. [для викладачів] / [Л. Г. Кайдалова, О. О. Телєжкіна, С. М. Полуян та ін.] - Х. : Вид-во НФаУ. - 2004. - 60 с. 5. Нагаєв В. М. Методика викладання у вищій школі: [навч. посіб.] / В. М. Нагаєв. - К. : Центр учбової літ., 2007. - 232 с. 6. Слєпкань 3. I. Наукові засади педагогічного процесу у вищій школі: [навч. посіб.] / 3. І. Слєпкань. - К. : Вища школа, 2005. - 239 с.

УДК 159.92

Г. В. Дьяконов,

доктор психол. наук, професор, Кіровоградський державний педагогічний університет імені Володимира Винниченка

\section{ДІАЛОГІЧНА КОНЦЕПЦІЯ ГУМАНІТАРНО-КУЛЬТУРНОЇ ОСВІТИ НА ПСИХОЛОГО-ПЕДАГОГІЧНОМУ ФАКУЛЬТЕТІ}

\begin{abstract}
Дьяконов Г. В. Діалогічна концепція гуманітарно-культурної освіти на психологопедагогічному факультеті.

У статті аналізується й обгрунтовується діалогічний підхід до побудови концепції гуманітарнокультурної освіти на психолого-педагогічному факультеті. Розкриваються засади, принципи, аспекти і перспективи розроблення і впровадження цієї концепції в практику професійної підготовки майбутніх практичних психологів і соціальних педагогів.

Ключові слова: діалогічний підхід, гуманітарно-культурна освіта, професійна підготовка майбутніх практичних психологів і соціальних педагогів.
\end{abstract}

Дьяконов Г. В. Диалогическая концепция гуманитарно-культурного образования на психологопедагогическом факультете.

В статье анализируется и обосновывается диалогический подход к построению концепции гуманитарно-культурного образования на психолого-педагогическом факультете. Раскрываются основы, принципы, аспекты и перспективы разработки и внедрения данной концепции в практику профессиональной подготовки будущих практических психологов и социальных педагогов.

Ключевые слова: диалогический подход, гуманитарно-культурное образование, профессиональная подготовка будущих практических психологов и социальных педагогов.

Diakonov H. V. Dialogic concept of human-cultural education in psychology and teachers'training faculty.

In the article analysed and grounded dialogical approach to the conception of humanitarian-cultural education on a psychological-pedagogical faculty. Grounds, principles, aspects and prospects of development and introduction of this conception in practice of professional preparation of future practical psychologists and social teachers, open up.

Key words: dialogical approach, humanitarian-cultural education, professional preparation of future practical psychologists and social teachers.

Теоретико-методологічні дослідження новітніх парадигм освіти й розвитку особистості у психології та педагогіці переконливо свідчать, що ідея діалогу і діалогічний світогляд органічно поєднують у собі культуроформувальний і гуманітарно-духовний потенціали становлення людини, громадянина, фахівця, творця $[4 ; 9 ; 10 ; 13]$. 